\title{
Natural Fecundity and Germination Characteristics of Selected Cyclopia (Honeybush) Species: Preliminary Findings
}

\author{
Mlamuli M. Motsa ${ }^{1,2}$, Cecilia Bester ${ }^{1}$, Margaretha M. Slabbert ${ }^{2}$, Mzabalazo Z. Ngwenya ${ }^{3} \&$ Mardé Booyse $^{3}$ \\ ${ }^{1}$ Crop Development Division, Agricultural Research Council Infruitec-Nietvoorbij, Stellenbosch, South Africa \\ ${ }^{2}$ Department of Horticulture, Faculty of Science, Tshwane University of Technology, Pretoria, South Africa \\ ${ }^{3}$ Biometry, Agricultural Research Council, Pretoria, South Africa
}

Correspondence: Cecilia Bester, Crop Development Division, Agricultural Research Council Infruitec-Nietvoorbij, Private Bag X5026, Stellenbosch, 7599, South Africa. Tel: 27-218-093-450. E-mail: besterc@arc.agric.za

\author{
Received: February 6, $2017 \quad$ Accepted: April 23, $2017 \quad$ Online Published: May 15, 2017 \\ doi:10.5539/jas.v9n6p154 URL: https://doi.org/10.5539/jas.v9n6p154
}

\begin{abstract}
Cyclopia Vent. (honeybush) is a South African herbal tea legume endemic to the Cape Floristic Region of South Africa. At present, knowledge of reproductive fitness (fecundity) between cultivated and undomesticated Cyclopia species is scant. Cultivated genotypes of C. genistoides (L.) R.Br. and C. subternata Vogel were evaluated for their potential to produce fruit and seeds in different localities spanning two years. Fecundity and germination were also determined from natural environment of each species and compared to cultivated species in order to determine the variation between species and between cultivated and non-cultivated species. Seeds collected were weighed to determined seed mass and evaluated for germination rate and cumulative germination per individual site. A fifth of flowers developing into a pod, averaged more initiated and filled seeds per pod in $C$. subternata than $C$. genistoides. Germination percentage was directly proportional to rate of germination in both species. Cyclopia subternata had a higher fecundity and germination than $C$. genistoides in both cultivated and natural environments. The study results assist in the further improvement of the genus through breeding new cultivars for seed with desired qualities for improving commercial characteristics; planning of seed orchards for seed production, selecting of best sites, assisting in choosing progenies for seed production and rehabilitation of degraded sites for the sustainable production of honeybush.
\end{abstract}

Keywords: fruit set, honeybush, seed germination, seed mass, seed production, seed set

\section{Introduction}

Fecundity (reproductive fitness) is defined by Muller-Laudau (2010) as the seed production of an individual plant in relation to the site in which it regenerates. Fecundity is important for reproductive success, timing of reproductive maturation, and in determining a population growth rate and species diversity (Schurr, Steinitz, \& Nathan, 2008; Qiu, Bai, Fu, \& Wilmshurst, 2010). Plants are variable and heritable variability causes some individual plants to reproduce and establish better than others (Pringle, Chen, \& Taylor, 2003). Understanding the processes and environmental conditions governing plant variation in reproductive performance is essential and provides important information on factors that characterise plant community structure and influence fecundity (Dainese, 2011). Plant variation arises due to the different parameters used when comparing fecundity associated with different characters, such as states of flowering or fruiting, related plant attributes such as fruit set and seed mass, germination rates and seed number. These fecundity parameters controls plant population dynamics and community structure, have strong adaptive implications in different environmental conditions as they can be used as quality estimators and future successes of offspring (Liu, Yan, Li, Ma, \& Ling, 2007; Braza, Arroyo, \& García, 2010; Qiu et al., 2010; Dainese, 2011).

Cyclopia Vent. species, indigenous to the Fynbos Biome of South Africa, belong to a largely unstudied leguminous genus of the Fabaceae family occurring within small areas in limited numbers or can be widespread on the coastal plains and mountainous regions in the Eastern and Western Cape Provinces of South Africa (Schutte, 1997). There are 23 known Cyclopia species of which six, C. genistoides, C. intermedia, C. longifolia, C. maculata, C. sessiliflora and C. subternata, are of commercial importance for use as an herbal infusion called 
honeybush tea. Honeybush tea is naturally sweet tasting and caffeine free. Although Cyclopia is commercially cultivated, wild harvesting still contributes about 70 percent of the total annual production, which diminishes natural populations due to an upsurge in unsustainable harvesting practices. Hence, commercial production becomes increasingly important to save the natural habitat and genepool of the species (E. Joubert, M. E. Joubert, Bester, De Beer, \& De Lange, 2011). Agronomic and horticultural measures have since been undertaken to commercialise honeybush, owing to its enormous international demand that outstrips local supply. However, this information is scarce since there are no scientific studies that have undertaken to study the agronomic and horticultural aspects of honeybush previously despite such efforts. A few studies have been recently undertaken which have looked at honeybush phenology (Motsa, Slabbert, Bester, \& Ngwenya, 2016), seed anatomy (Koen, Slabbert, Bester, \& Bierman, 2016), root cutting and growth media effect (Mabizela, Slabbert, \& Bester, 2016), seed volatiles during germination (Motsa, Slabbert, Bester, Mokwena, \& Taylor, 2017).

Presently, no studies have attempted to investigate the seed production potential of this indigenous legume, yet such studies are critical to allow for selection of species and genotypes for improved agronomic and horticultural aspects such as yield and quality of seed, good seed germination and seedling establishment. This will assist the industry, small-scale farmers and communities cultivating honeybush in selecting of suitable sites and assisting in choosing progenies for seed production. Furthermore, such studies will assist in evolutionary studies, conserving endangered species, and managing biodiversity (Price, Campell, Waser, \& Brody, 2008). A number of Cyclopia clonal genotypes were collected by the Agricultural Research Council Infruitec-Nietvoorbij (ARC) from different geographical areas and cultivated under similar environments as part of managing and conserving species biodiversity and extinction (Bester et al., 2013). However, introduction of species genotypes to new environments can change their phenotype either due to escaping from native competitors or because the environment possesses growth conditions that are conducive for prolonged growth, thus critically determining colonization (Maron, Vilá, Bommarco, Elmendorf, \& Beardsley, 2004). The study aimed at determining the potential of selected genotypes of two Cyclopia species selected in seven sites to produce pods and initiate seeds (fecundity); and the speed and percentage germination of their harvested seeds. Fecundity and germination were monitored in order to evaluate if there are differences between cultivated species in different geographical locations; and between cultivated and wild (non-cultivated) growing species plants. These results will enable honeybush breeders to select best sites and genotypes for honeybush seed production.

\section{Materials and Methods}

\subsection{Study Species, Population and Sites}

Rooted cuttings of $C$. genistoides (L.) R.Br. and C. subternata Vogel (currently advocated for commercialisation on a large scale) were investigated from July 2013 extending to January 2015. Initially, the two cultivated species were monitored and evaluated in Elsenburg $\left(33.502687^{\circ} \mathrm{S}, 18.504760^{\circ} \mathrm{E}\right)$ located in the Stellenbosch area; Kanetberg $\left(33.93763^{\circ} \mathrm{S}, 21.06561^{\circ} \mathrm{E}\right)$ located near Barrydale (C. subternata) and Toekomst $\left(34.54340^{\circ} \mathrm{S}\right.$, $19.87983^{\circ} \mathrm{E}$ ) located near Bredasdorp (C. genistoides). Wild growing species were monitored in Koksrivier $\left(34.69463^{\circ} \mathrm{S}, 19.60937^{\circ} \mathrm{E}\right)$ near Pearly Beach $(C$. subternata $)$ and Gouritsmond $\left(34.35955^{\circ} \mathrm{S}, 21.79324^{\circ} \mathrm{E}\right)$ in the Albertinia district (C. genistoides). However, after the loss of the Kanetberg and Gouritsmond sites due to veld fires, and the Koksrivier site due to flooding in 2013, new sites were sampled in 2014 for cultivated $C$. subternata in Nietvoorbij $\left(33.90619^{\circ} \mathrm{S}, 18.87031^{\circ} \mathrm{E}\right)$ located in the Stellenbosch area; for wild C. subternata in Guava Juice $\left(34.25138^{\circ} \mathrm{S}, 24.21184^{\circ} \mathrm{E}\right)$ in the Clarkson area of the Eastern Cape Province; and for wild $C$. genistoides in Koksrivier site $\left(34.69492^{\circ} \mathrm{S}, 19.60410^{\circ} \mathrm{E}\right)$ near Pearly Beach (Figure 1). The coordinates of each site were located using a GPS (Garmen Oregon 550) with weather data presented in Table 1 of Motsa et al (2016). 


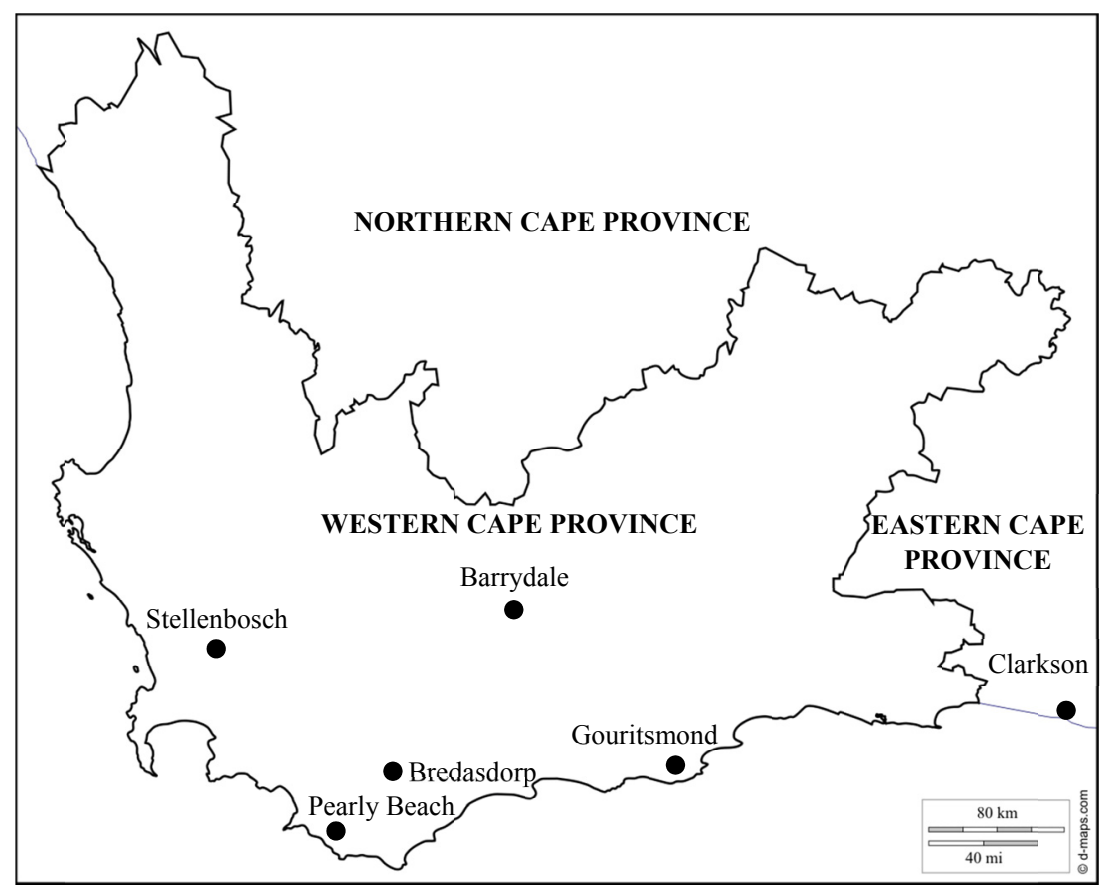

Figure 1. Map indicating the different areas where the Cyclopia species were monitored from budding to seed production in the Western and Eastern Cape Provinces, South Africa

\subsection{Sampling}

Sampled plants and inflorescences were marked with chevron tape. Initially, five genotypes per species, two plants per genotype), five inflorescences per plant and 50 flower buds per inflorescence (from the tip of the inflorescence) were sampled each in two different cultivated farms per species for data gathering during 2013 (July to August). Simultaneously, a natural (uncultivated) site was selected and 10 individual plants were sampled with equal number of inflorescences and flowers as in the cultivated sites. The trial was modified in 2014 to three plants per genotype and 13 genotypes for C. subternata, and five plants for each of eight genotypes for $C$. genistoides for the cultivated sites and to 40 plants in the natural environment. In both species, two inflorescences were randomly selected per plant since previous data (2013) did not indicate any major statistical differences between inflorescences (data not shown). A length of $50 \mathrm{~cm}$ was measured from the tip of each inflorescence and marked with white labelled tags and flower buds counted and recorded. Labelling of clustered inflorescences was avoided due to difficulties experienced during bagging of pods (in 2013). Due to the growth form of a majority of the $C$. genistoides plants, the whole inflorescence was used for counting the number of visible flower buds. Masking tape was used to mark the end point where flower buds were counted in order to avoid over- or under-counting during pod count.

Data gathered involved counting and recording the number of flower buds and pods in order to estimate fruit set, seed set, mean seed mass and total number of seeds (Dainese, 2011). During the fruiting phase, counted pods were covered with transparent bags in order to avoid pods splitting open and dispersing seeds. Pods were harvested upon maturity depending on the species' fruiting period per site (November to January) just after pod maturation to minimise splitting of pods, and transported to laboratory in brown paper bags stacked in plastic bags. In the laboratory, all material and surfaces used were first surface sterilised with alcohol in order to minimise laboratory contamination of seeds. Pods from each inflorescence were manually opened and their seeds counted and weighed in an OHAUS Analytical Plus scale. Thereafter, seeds were put in labelled transparent zip lock bags and refrigerated $\left(4{ }^{\circ} \mathrm{C}\right)$ before testing for differences in rate and percentage germination. Seeds were scarified by soaking for 60 minutes in $98 \%$ sulphuric acid, a standard practice as described by Bester and Cronje (2013). In order to prevent secondary contamination, all other materials including laboratory tables, Petri dishes, spatula and growth chambers were surfaced sterilized with $90 \%$ alcohol. 


\subsection{Data Collection}

\subsubsection{Fecundity Calculation}

Fecundity was measured by determining the percentage fruit (pod) set which is the total number of initiated pods over the initial number of counted flowers, and seed set as the ratio of the number of initiated seeds over the number of counted pods (Parra-Tabla, Vargas, \& Eguiarte, 1998; Kéry, Marrhies, \& Spillmann, 2000; Snow et al., 2003; Braza et al., 2010). Thereafter, seeds from each inflorescence were randomly weighed to determine the mass of each seed lot per inflorescence. The mean seed mass was calculated by dividing the mass of harvested seeds by the number of counted seeds, since using threshold of seed mass per 100 seeds was not feasible due to that some genotypes plants produced far less number of seeds (Kéry et al., 2000). Lastly, the total number of seeds per individual plant was calculated as the total seed mass per plant divided by the mean seed mass (Snow et al., 2003; Dainese, 2011).

\subsubsection{Seed Germination}

Twenty-five seeds replicated four times were placed on top of two layers Whatman No. 2 round $90 \mathrm{~mm}$ filter paper moistened with $5 \mathrm{~mL}$ distilled water lined in $90 \mathrm{~mm}$ plastic Petri dishes for each clonal and wild genotype plant (International Seed Testing Association, 2008). In genotypes where harvested seeds were less than 100, the available seeds were equally divided into four replicates. Treatments were arranged using a completely randomized design for all experiments. Seed were germinated at $19{ }^{\circ} \mathrm{C}$ under interrupted darkness according to Koen et al. (2016). Seeds were considered to have germinated once the radicle has visibly protruded from the testa and were counted and removed, and expressed as a percentage of the total number of tested seeds.

\subsection{Statistical Analysis}

A completely randomised factorial design model was used in the ANOVA wherein the factors were species, type. Trials were conducted over two years. The variables measured were continuous data and were subjected to analysis of variance (ANOVA) using General Linear Models Procedure (PROC GLM) of SAS software (Version 9.2; SAS Institute Inc, Cary, USA). The Shapiro-Wilk test was performed on the standardised residuals to confirm normality (Shapiro \& Wilk, 1965). The Fisher t-test with Least Significant Difference (LSD) was used to compare treatment means at $5 \%$ level of significance. The germination experiment was carried out for 14 days with daily observations. To analyse germination rates the Gompertz function (Du Preez \& Sales, 1997), which is described by:

$$
\text { Germination rate }=a \times \mathrm{e}^{(-\exp (-b \times(\text { Day }-c))}
$$

Where, in $a$ : germination rate at the end of observation period (total germination); $b$ : germination rate (i.e. the rate at which seeds germinate); $c$ : time at which the daily germination rate reaches its maximum value.

This was fitted to the data using Proc NLIN of SAS software (Version 9.2; SAS Institute Inc, Cary, USA). From the fitted data the time taken to reach $90 \%$ germination ( $T_{90}$ germination) of the seeds was then determined by,

$$
T_{90}=c+\frac{\log (-\log (\theta / a)}{-b}
$$

The regression coefficients (parameters) were then compared by ANOVA and a student t-test.

\section{Results}

\subsection{Seed Production}

The number of initiated pods from flowers (fruit set) was significantly higher $\left(\mathrm{LSD}_{0.05}=7.9433\right)$ for clonal $C$. genistoides in 2013 (25.2\%) compared to C. subternata clonal (13.6\%) and wild (10.8\%) genotypes (Figure 2a). In contrast, in 2014 fruit set of clonal C. genistoides $(18.51 \%)$ did not differ significantly $\left(\operatorname{LSD}_{0.05}=9.7112\right)$ to that of C. subternata clonal (22.5\%) and wild (23.6\%). However, fruit set of clonal C. genistoides significantly differed to the $1.6 \%$ attained from their wild counterparts. No significant differences were observed between fruit set of clonal and wild C. subternata. The average seed set ratio was significantly higher $\left(\mathrm{LSD}_{0.05}=1.0955\right)$ for clonal and wild C. subternata (3.7 and 3.0 respectively) in 2013 than the clonal C. genistoides (1.1) (Figure $2 b)$. Seed set was significantly higher $\left(\mathrm{LSD}_{0.05}=0.2914\right)$ in 2014 for clonal C. subternata $(3.5)$ than their wild counterparts (2.6). Moreover, both clonal and wild C. subternata was significantly higher than clonal and wild $C$. genistoides. Seed set of clonal plants $(1.8)$ was significantly higher $\left(\operatorname{LSD}_{0.05}=0.2914\right)$ than natively $(0.5)$ growing C. genistoides. 
The mean seed mass of clonal plants $(0.0129 \mathrm{~g})$ was significantly higher $\left(\mathrm{LSD}_{0.05}=0.0014\right)$ than natively $(0.0113 \mathrm{~g})$ growing C. subternata and clonal C. genistoides $(0.0104 \mathrm{~g})$ in 2013 (Figure 2c). However, in 2014, seed mass of wild $C$. genistoides $(0.00302 \mathrm{~g})$ was significantly lower $\left(\mathrm{LSD}_{0.05}=0.0033\right)$ compared to all the others, with no differences between clonal $(0.0113 \mathrm{~g})$ and wild $(0.0109 \mathrm{~g})$ C. subternata and clonal $C$. genistoides $(0.0129 \mathrm{~g})$. A significantly higher $\left(\mathrm{LSD}_{0.05}=47.607\right)$ average number of seed was harvested from clonal C. subternata in 2013 (116.51) (214.37) than clonal C. genistoides (51.85), but did not significantly differ to natively growing $C$. subternata genotypes (104.13). Similarly, in 2014 no significant differences $\left(\operatorname{LSD}_{0.05}=\right.$ 41.191) were attained in seed number of clonal (221.38) and natively (214.37) growing C. subternata. However, seed number harvested from $C$. subternata significantly differed to that of both clonal (63.81) and natively (0.10) growing $C$. genistoides in 2014. A significantly lower number of seed was harvested from natively compared to clonal growing C. genistoides (Figure 2d).
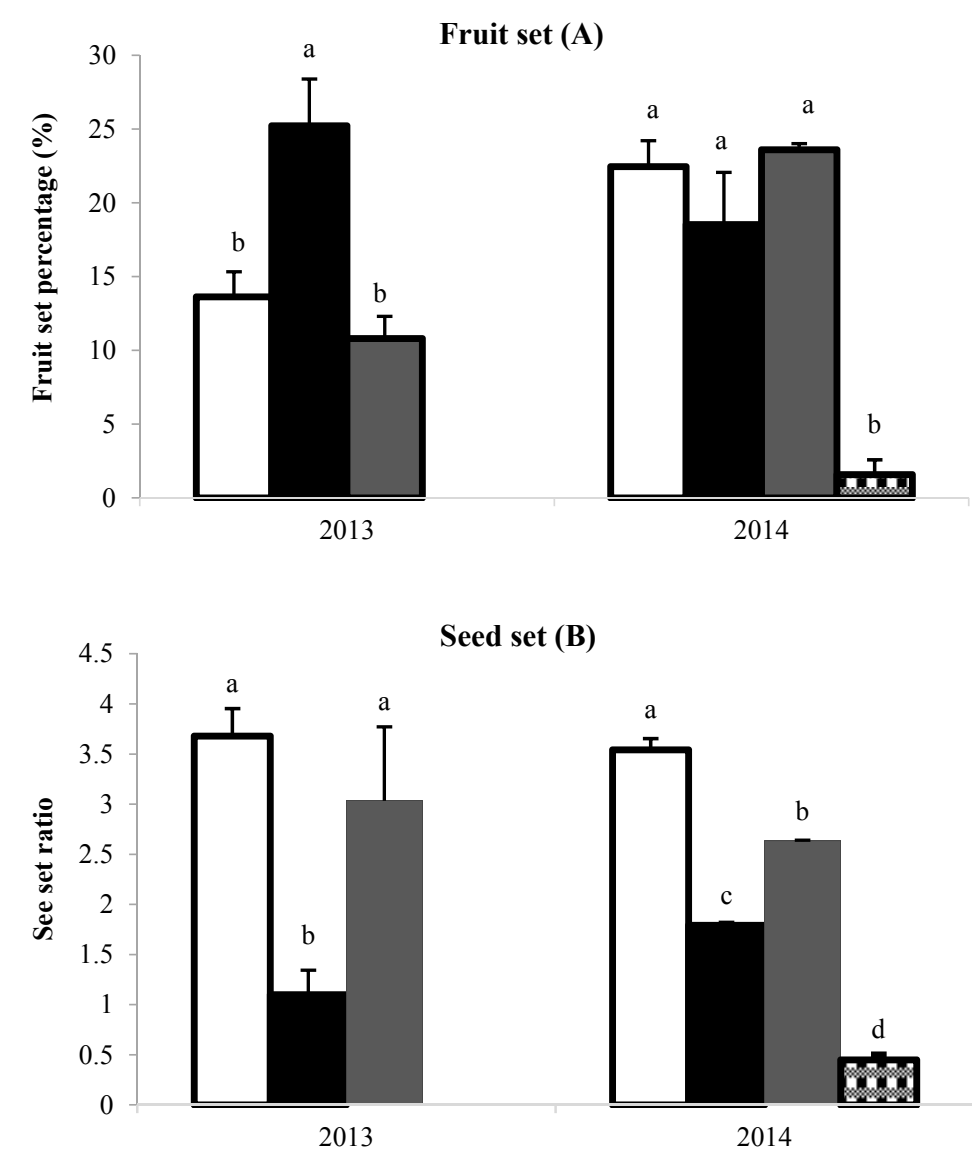

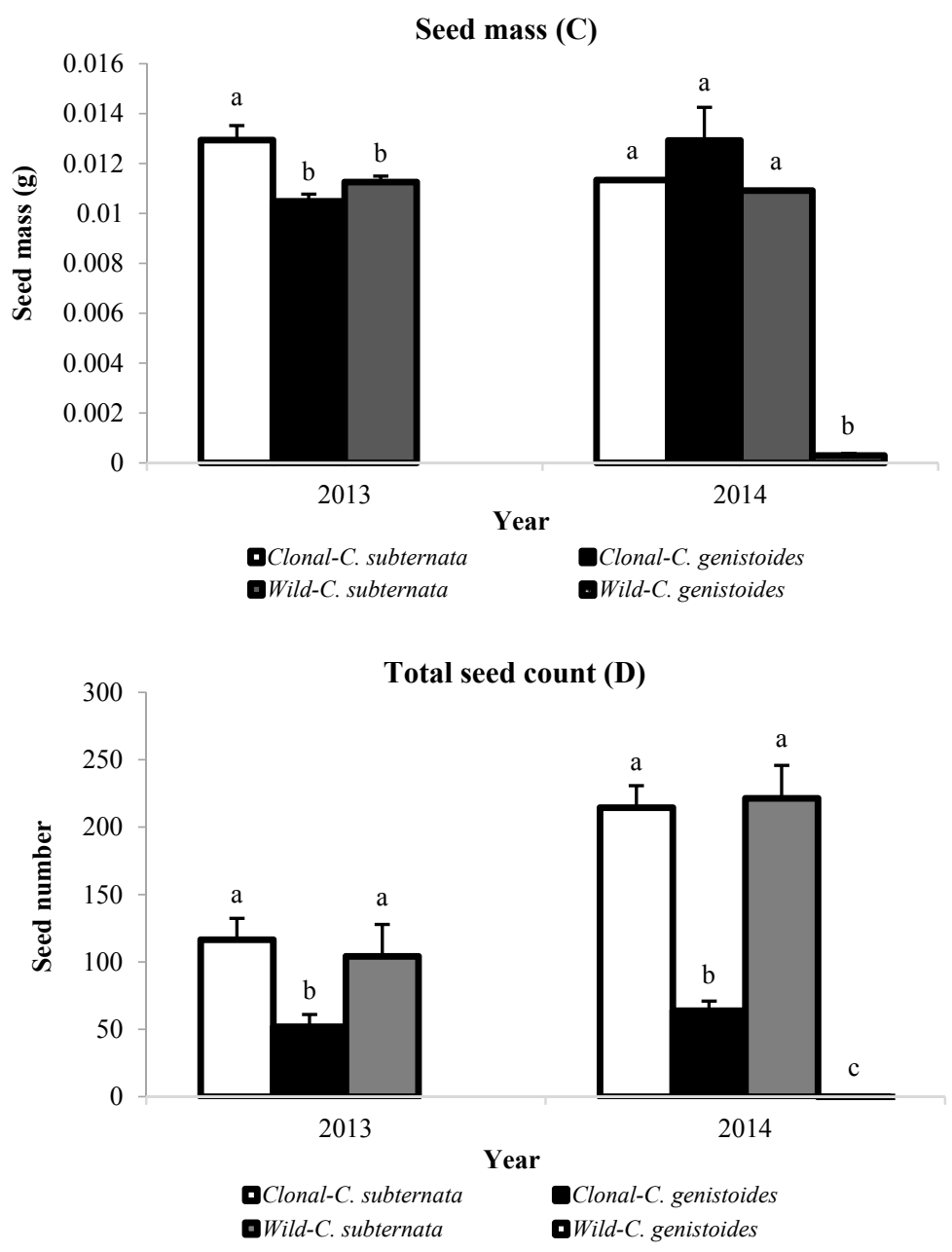

Figure 2. The average fruit set percent, seed set ratio, seed mass and total harvested seeds of clonal and wild genotypes of both Cyclopia genistoides and C. subternata in 2013 and 2014

\subsection{Seed Germination}

Seeds of clonal C. subternata (21.9 days) and C. genistoides (22.2 days) germinated ( $\mathrm{T}_{90}$ germination) significantly faster $\left(\mathrm{LSD}_{0.05}=4.5354\right)$ in 2013 than seeds from natively growing C. subternata (30.0 days) (Figure 3a). No significant differences $\left(\mathrm{LSD}_{0.05}=4.5354\right)$ were observed in $\mathrm{T}_{90}$ germination of clonal $C$. genistoides and $C$. subternata. The $\mathrm{T}_{90}$ percent germination of 16.1 days for natively growing $C$. genistoides seed in 2014 although appeared faster did not however differ significantly $\left(\mathrm{LSD}_{0.05}=13.177\right)$ to the 19.9 days, 20.4 days and 29.1 days for wild and clonal C. subternata and clonal C. genistoides, respectively. Germination percentage was significantly higher $\left(\mathrm{LSD}_{0.05}=10.737\right)$ for clonal $(64.8 \%)$ than wild $(51.0 \%)$ C. subternata seed in 2013, but both species types' germination did not significantly differ to the $60.1 \%$ attained from clonal $C$. genistoides (Figure 3b). However, in 2014 the germination percentage did not significantly differ $\left(\mathrm{LSD}_{0.05}=\right.$ 26.703 ) between species types' being $50.3 \%, 66.7 \%, 69.3 \%$ and $71.4 \%$ for clonal and wild C. genistoides, and clonal and wild C. subternata respectively. 

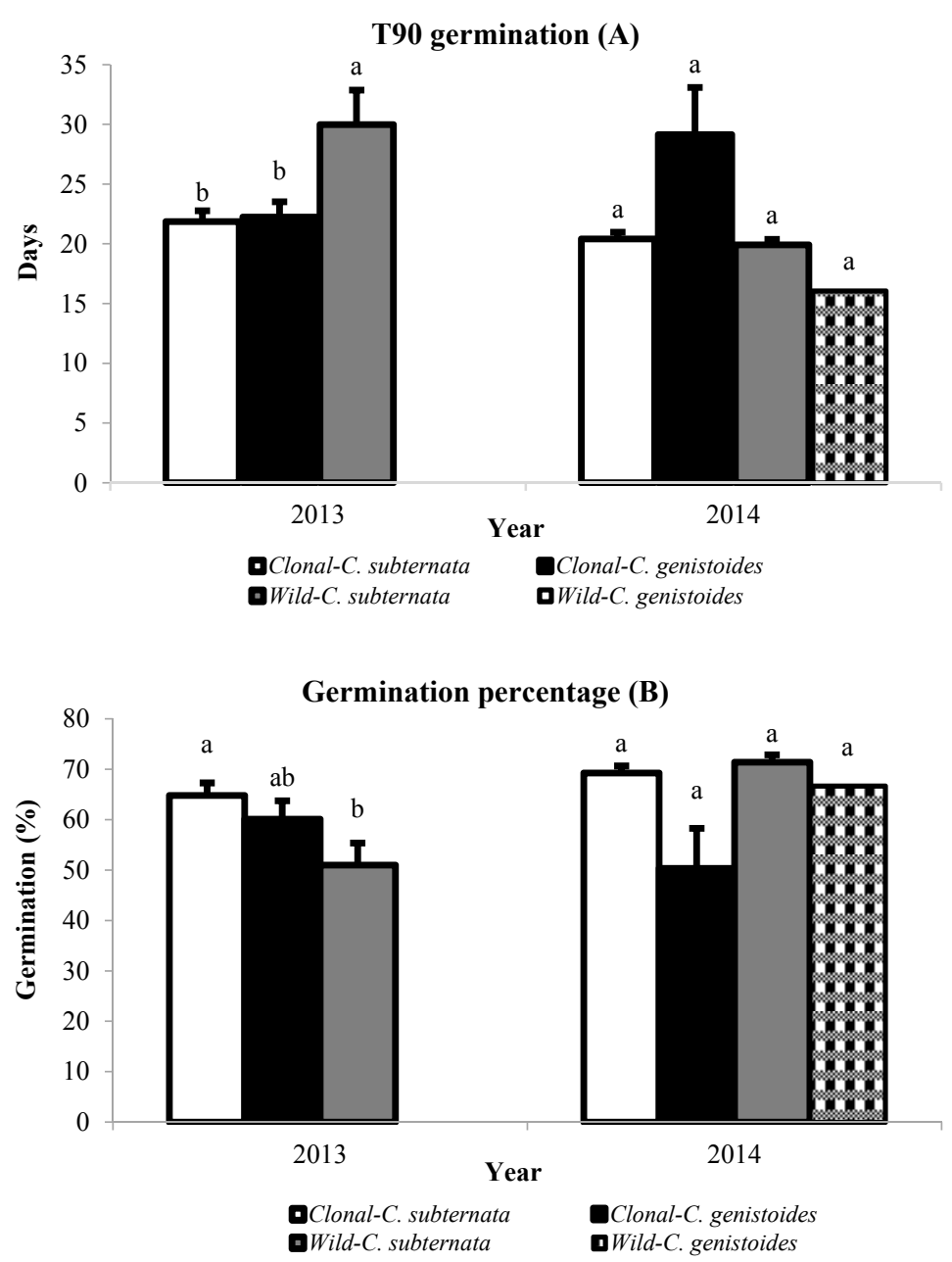

Figure 3. The average time taken to achieve 90 percent $\left(T_{90}\right)$ and final percent germination of clonal and wild genotypes of both Cyclopia genistoides and C. subternata in 2013 and 2014

\section{Discussion}

\subsection{Fecundity}

\subsubsection{Fecundity Variation between C. genistoides and C. subternata}

In this study the major studied fecundity parameters examined; fruit (pod) set, seed set, seed mass and total number of seeds per plant varied between and within the two Cyclopia species, C. genistoides and C. subternata. The study indicated higher reproductive fitness for $C$. subternata as a flower of $C$. subternata averaged more initiated and filled seeds per pod compared to C. genistoides. This can be ascribed to the fact that C. subternata partition more of its resources to seed production since it often fails to survive fire disturbances and thus regeneration depends exclusively on seeds that normally germinate after a fire event. In contrast, $C$. genistoides directs more of its nutrients and resources to a lignotuber for regeneration after fire disturbances thus does not entirely rely on seeds for regeneration (Schutte, 1997). The variation between the two species of different life strategies is not uncommon, hence non-sprouters are known to have a higher flowering and seed production whilst sprouters have higher conservative use of nutrients (Sardans \& Peñuelas, 2013). The life history regeneration strategies (sprouters and nonsprouters) of the Cyclopia species will affect their seed production strategies.

Variation within and between species was also observed between the two years, and can be explained by the differences in climatic conditions, geographic variables, soil conditions, site quality, genetic factors and genotypes used (García, Zamora, Gómez, Jordano, \& Hódar, 2000; Susko \& Lovett-Doust, 2000; Ayari et al. 2011; Podleśny \& Podleśna, 2012). Legumes have a very high yielding dependency on weather conditions with temperature and drought primarily affecting critical stages of plant development such as flowering to pod set 
thus altering the growth season, impeding seed maturation consequently affecting seed production (Thuzar, Puteh, Abdullah, Lassim, \& Jusoff, 2010; Valtuéna, Ortega-Olivencia, Rodríguez-Riaño, \& López, 2010; Ayari et al., 2011; Podleśny \& Podleśna, 2012). Regeneration failure may be expected in years where climatic conditions favour species to produce more pods but initiate and fill less seeds, ultimately leading to species extinction in accordance with García et al. (2000). Climatic conditions also vary the availability of resources by the mother plants during seed development (Susko \& Lovett-Doust, 2000). As resource availability allows in favourable periods, fruits of highest quality are matured and the remainder aborted (Lee \& Bazzaz, 1982; Teixera, Pareira, \& Ranga, 2006; Dao, Diallo, \& Kabore-Zoungrana, 2012). Differences in Cyclopia intra- and inter-species pod development and filling can be due to resource accrual and partitioning during seed development among plants within the same growing season (Kéry et al., 2000; Carrió, Jiménez, Sánchez-Gómez, \& Güemes, 2009; Valtueña et al., 2010). Therefore, genotypic differences in utilisation of photoassimilates or other nutrients which are reliant on the timing and duration of phenology, physiological constraints, climatic conditions and maternal effects can affect reproductive fitness in the Cyclopia species.

Parameterising fecundity in this study was difficult since the Cyclopia genotypes were of different plant size, age and establishment across the different sites. There is a positive correlation between fecundity and life span (Lee \& Bazzaz, 1982; Valtueña et al., 2010). Fecundity increases when plants physiologically mature and become established with years with wide cross pollination. These plants tend to produce more fruit per inflorescence and have more accumulates and photosynthetic reserves to maintain initiated fruit during the flowering period than smaller plants. In accordance, clonal genotypes of $C$. subternata growing at the Elsenburg site had a lower pod set compared to their five year older genotypes at Kanetberg and Nietvoorbij. Therefore, use of larger and mature plants to fully express plants reproductive potential when evaluating seed production is recommended. However, plants that have past their physiological maturity may display poor reproductive fitness compared to young physiologically mature growing plants. Therefore, fecundity of Cyclopia species may be expected to increase in years as plants physiologically mature and develop due to larger plants having more resources for seed production, hence maturing a greater proportion of seeds per ovule than would smaller younger plants or plants that have past their physiological reproductive peak.

\subsubsection{Fecundity Variation between Cultivated and Wild Species}

Fecundity of Cyclopia varied between cultivated and non-cultivated (wild) species in both years although intra-species variations were observed. It is however difficult to really ascertain the higher reproductive fitness of cultivated over and wild species since they were not grown in uniform conditions which would have eliminated differences due to environmental variation. However, separation of a portion of a plant and selection under environmental conditions different from those operating in nature, overtime leads to cultivated plants becoming morphologically and physiologically modified relative to their wild counterparts (Paz \& Vázquez-Yanes, 1998; Alexander, Cummings, Kahn, \& Snow, 2001; Rojas-Aréchiga, Casas, \& Vázquez-Yanes, 2001). Therefore, differences in morphological and physiological traits would be expected, and cultivated species re-integration in native environments may swamp natively growing species and alter community structure and function provided the conditions they are introduced to are uniform and encourage improved reproductive fitness (Herget, Hufford, Mummey, \& Shreading, 2015). Monitoring of the cultivated species genotypes in native environments suitable for their grown and development is essential before conclusions can be drawn about their effectiveness over their native counterparts.

Cultivated species genotypes may not perform as good when grown in native or simulated wild environmental conditions, since they, may not have a competitive advantage at highly invaded areas compared to adapted wild species (Herget et al., 2015). However, morphological divergence from wild populations is likely genetically based or due to artificial selection since wild species retain their morphological features when cultivated (Rojas-Aréchiga et al., 2001). Despite the overall advantage of the cultivated Cyclopia genotypes, in each studied fecundity parameter, wild genotypes performed as well or better when compared to one or more cultivated genotypes in accordance with Paz and Vázquez-Yanes's (1998) study of wild and cultivated Carica papaya $\mathrm{L}$. Intra-species variations could have been a result of altering the study design in 2014 which lead to differences in plant size and age (especially since the size of the wild site plants was unknown); number of genotypes, plants, inflorescences and sites used for sampling between the two years due to site losses in 2013 through natural fires and flooding, which complicated comparisons and deductions. Biotic and abiotic effects of the different sites where the Cyclopia species were monitored could have also had a significant factor in varying fecundity since an individual plant's fitness is dependent on the prevailing conditions in which it regenerates (Muller-Lauder, 2010). As a result, some plants will be more successful than others due to heritable variation (Pringle et al., 2003). In C. genistoides, cultivated clones had a significantly higher number of harvested seed 
compared to natively growing species probably as a result that the wild genotypes used in 2014 were recovering from natural veld fires hence resources could have mostly been directed to vegetative than reproductive growth.

Other factors such as the degree of inbreeding and/or self-incompatibility can alter plant reproductive fitness by their variation between lower and higher seeding genotypes within species (Lee \& Bazzaz, 1982; Ehrlén, 1992; Elliot \& Ladd, 2002; Griffin \& Barret, 2002; Carrió et al., 2009; Dao et al., 2012). Genetic variation between and within species may give valuable information on crosses that can help augment fecundity since genetically inferior plants (smaller) produce more non-viable ovules or abort their embryos early compared to larger plants (Burton \& Husband, 2001; Griffin \& Barrett, 2002). The improved performance between cultivated clones grown between geographic areas may point to that they were attuned to the climatic conditions of that region, thus indicating adaptability. This can additionally be of importance in their screening and evaluating for adaptability and growth characteristics which will be fundamental in breeding programmes.

Predation of fruit or seed, affect seed recruitment (Lee \& Bazzaz, 1982; Teixeira et al., 2006; Dao et al., 2012 Larios, Búrquez, Becerra, \& Venable, 2014). This significantly caused differences in the number and mass of harvested seeds. In this study fruits were predated upon by suspected mice and baboons, whilst seeds were foraged by beetles identified as Bruchidius species from the Chrysomelidae: Bruchinae family. Variations in the dominance of predators is caused by the host species, weather conditions and impact of habitat disturbances within cultivated honeybush stands; determined by the seasonal availability of resources and responses to environmental conditions, with higher temperatures favouring predatory taxa such as wasps and beetles (Slabbert, 2016). Pod development and seed maturation in Cyclopia coincides with the hot dry summer condition in late October to December (Motsa et al., 2016), that could favour fruit and seed predation thus affecting fecundity. According to Slabbert (2016) C. genistoides (sprouter) resisted insect pest damage more than C. maculata (non-sprouter) indicating phenology and life history importance of the host plant. Hence availability of resources may be more in non-sprouters (e.g. C. subternata) pods and seeds which may be enough to satiate the energy needs of predators than in sprouters (e.g. C. genistoides) because seeders allocate most of their resources to above ground parts compared to sprouters. Therefore, by natural selection (predation), seed recruitment of the Cyclopia species could have been affected, contributing to the observed differences in fecundity between species.

Pollen limitation or pollinators could also have affected Cyclopia fecundity due to a shortage of suitable pollen grains, inadequate pollen from either incompatible pollen or high levels of pollen sterility or fungal-infected pollen received by flowers during fertilisation (Ehrlén, 1992; Elliot \& Ladd, 2002; Valtueña et al., 2010); directional movements of pollinators during foraging, due to sensitivity to nectar rewards (Carrió et al., 2009; Thuzar et al., 2010) or plants flowering period coinciding with unfavourable weather conditions (Burgos, Grez, \& Bustamante, 2008; Price et al., 2008). Cyclopia species produce an abundance of flowers and are mostly pollinated by monkey beetles (Scarabaeidae) according to M. Joubert and E. Joubert (2012). Genotypes flowers with high nectar production can be expected to attract more pollinators leading to a higher rate of pollination, and thus probably higher fertility. However, differences may occur probable due to geographical environmental effects (Sharma \& Bakshi, 2014) that may affect pollen and/or pollinator abundance and selectivity. Cyclopia flowers may thus provide pollinators with floral rewards during flower visits that balance their energy needs, which are dependent on genotypic phenological differences and nectar production, and thus pollinators may alter their foraging behaviour consequently varying fecundity. The effect of pollen limitation and pollinator mechanism has not been investigated and further studies are needed to determine their significance in plant reproductive success of the genus.

\subsection{Germination Characteristics}

\subsubsection{Germination Variation between C. genistoides and C. subternata}

In both species germination percentage was directly proportional to rate of germination where genotypes with a faster germination rate in turn had a higher germination percentage. Generally, germination trend in $C$. subternata was higher compared to C. genistoides, although statistically was not different. Species inter-specific differences in germination can be caused by seed mass, environmental conditions, genetic causes, infertility of some seeds and dormancy mechanism of fertile seeds that have significant effects on germination, emergence, surviving, persistence or invasiveness of a species in a habitat (Susko \& Lovett-Doust, 2000; Vitasse, Delzon, Bresson, Michalet, \& Kremer, 2009; Bognounou, Thiombiano, Oden, \& Guinko, 2010). Plants originating from larger seeds are expected to have a higher probability of germination, and survival (Larios et al., 2014) since the seed embryo is fully reliant on seed reserves during germination and seedling development (Löwe \& Dillenburg, 2011). Contrary to this study finding, smaller seeded genotypes had a faster and higher germination in $C$. 
subternata, whilst in C. genistoides only one genotype, had a higher seed mass, with a faster and higher germination than all other genotypes (unpublished data). Smaller seeded species are known to be superior colonisers due to faster and higher germination and establishment, while larger seeds develop into larger seedlings that better tolerate lack of resources or hazards associated with establishment (Larios et al., 2014).

When plants from different geographical regions are grown in a common environment variation due to genetics is cancelled out, such as seed mass, and differences in rate and percentage germination in Cyclopia may be due to other unknown factors. Therefore, rate and percentage of germination could thus increase, decrease or remain unaffected by differences in seed size (Susko \& Lovett-Doust, 2000). Where germination rate and percentage was similar for genotypes from both species, it may imply that allocation of resources to reproduction may not vary greatly within species (Bognounou et al., 2010). Further investigating of the intraspecific variation in seed mass of Cyclopia is critical for their hardiness to disturbance. The survival ability of germinating Cyclopia seedlings may thus be determined by environmental conditions post germination.

\subsubsection{Germination Variation between Cultivated and Wild Species}

Generally, differences were only observed in C. subternata germination rate in both years with no differences in germination percentage. Differences in germination among species in different geographic regions are inevitable (Susko \& Lovett-Doust, 2000; Aref, El Atta, Al Shahrani, \& Mohamed, 2011) since conditions prevailing during seed development and maturation may differ among sites. The environment experienced after dispersal or harvesting strongly affect germination, hence certain environmental conditions may permit germination after dormancy is broken whilst other may not (Donohue et al., 2005; Das, 2014). Plants species vary their germinability among and within populations and among and within individuals due to genetic or phenotypic variation caused by the native conditions under which the seed is matured (Bognounou et al., 2010; Hay \& Probert, 2013; Batabyal, Dalal, \& Tah, 2014). Therefore, harvesting of Cyclopia seeds from different geographic sites simultaneously could have led to high proportions of immature seeds (due to variability in flowering) where conditions were not optimal for seed maturation (Hay \& Probert, 2013). This according to Silvertown (1984) leads to variation in germination when seeds are tested. A post-harvest ripening treatment is therefore crucial for quick and uniform germination (Das, 2014), since wild and cultivated species differ in dormancy mechanisms and light sensitivity, thus varying germination pattern (Paz \& Vázquez-Yanes, 1998; Rojas-Aréchiga et al., 2001).

Timing of germination is crucial to the lifetime performance of the resulting plant since it affect seedling survivorship, total lifetime fitness, life-history expression and selection of germination characters (Donohue et al., 2005). Therefore, identification of optimal harvest time for maximal germination in Cyclopia species across geographical sites is imperative. This will assist in determining places colonised by species and/or species competitive dominant ability. In some genotypes, germination did not vary according to seed provenance and may imply that the seed had more or less the same germination energy in all the geographic areas. Germination of cultivated species may thus affect the ability to establish in new locations, but post-germination survival may be crucial in adaptation in new locations, hence the need to study survival of transplanted seedlings to new environments. This will strongly affect the rate at which species can expand their ranges and adapt to new geographical areas. Another factor could be that the seeds were not germinated at optimal temperature since plants species have different cardinal temperatures at which germination occurs (Motsa, Slabbert, Van Averbeke, \& Morey, 2015). However, germination at temperature $\left(19^{\circ} \mathrm{C}\right)$ may be within the limits of Cyclopia germination since Koen et al. (2016) reported highest seed germination of Cyclopia at $15{ }^{\circ} \mathrm{C}$. However, studies investigating their cardinal temperatures are still lacking.

Seed germination, amongst other factors, is regulated by the position of the pod on the plant (Toth, Dragomir, \& Neagu, 2013). Diversity may arise within a seed pod or between pods resulting from differences in the time of year at which the pod was produced, which affects germination ability between seeds and leading to a certain degree of dormancy (Silvertown, 1984; Mohammadi, Khah, \& Bannayan-Aval, 2011). Modifying the traditional time of harvest probably could help improve germination in Cyclopia seeds as observed in harvesting okra seed, where pods are harvested whilst slightly immature preventing them from completing desiccation thus reducing dormancy (Mohammadi et al., 2011). Physical dormancy arises whilst pods remain longer on the plant as they ripen during periods of high temperatures especially dry conditions (Mohammadi et al., 2011; Toth et al., 2013). In legumes, dormant seed are associated with resistance to extinction by natural hazards (Silvertown, 1984), as well as longer viability and thus may affect germination pattern (Aref et al., 2011), resulting in a lack of uniformity in seed germination (Mohammadi et al., 2011). Very hot dry summer conditions prevail during pod ripening of the two Cyclopia species (Motsa et al., 2016) which can lead to activation of coat imposed dormancy thus safe guarding against unfavourable conditions during regeneration of dispersed seeds. 


\section{Conclusion}

In both cultivated and natural environments, it can be expected that a higher number of seed will be initiated and filled per pod in C. subternata than C. genistoides. Therefore, C. subternata could be superior coloniser and will likely have a higher population and better establishment rate than C. genistoides. Seed recruitment in non-sprouters must therefore occur in every generation if species are to persist. In contrast, $C$. genistoides may have higher risks of regeneration failure through seed to keep a population persistent and thus prone to extinction. Differences in the ecological adaptations, population densities, habitat specificity, allocation of resources and seedling production is therefore possible between Cyclopia sprouters and non-sprouters. Continuous harvesting of individual plants annually should be avoided, to allow plants to produce seeds in order to preserve the genetics and ensure population persistence. To draw conclusive results, further studies are needed on the effect of factors such as climatic conditions, genetics, pollination mechanisms, internal physiological stresses, amongst others on fecundity and timing of germination. However, one or more factors may act synergistically in affecting these traits. Cultivated species may provide some advantage for establishment of new sites since natural stands of Cyclopia species are under threat of extinction, necessitating restoration of populations. However, this may require use of species genotypes adaptable to a wider range of geographic conditions to increase the likelihood that plants will adapt to site conditions, maintain genetic diversity and improve the long term sustainability of the restored population. Even so, complications may still arise when cultivated species are used for restoration of wild sites since wild and cultivated species may differ in other traits besides the ones highlighted in this study. Seed banks to conserve germplasm are therefore crucial for Cyclopia species in order to help improve seed quality and yield, however, the challenge is that currently there are no specific standards for conservation of both cultivated and wild Cyclopia seeds. These findings will assist in planning of seed orchards for seed production, selecting of best sites, assist in choosing genotypes for seed production; and rehabilitation of degraded sites for the honeybush sustainability.

\section{Acknowledgements}

This study was supported by a grant from the Department of Science and Technology (DST), Monetary Treasury Economic Fund (MTEF), Agricultural Research Council (ARC) Infruitec-Nietvoorbij and Tshwane University of Technology (TUT), in South Africa. We thank the Western Cape government, Guava Juice community, Reins Private Nature Reserve, F. J. Joubert and G. v. Z. Joubert for proving their farms for sampling and monitoring of the honeybush species. Special thanks to Marlise Joubert of the Crop Development Division, ARC Infruitec-Nietvoorbij, for her honeybush cultivation knowledge, identification of the different honeybush sites and species, and introduction to farmers and communities (Eastern and Western Cape Province). We thank the personnel of the ARC for their assistance during data collection.

\section{References}

Alexander, H. M., Cummings, C. L., Kahn, L., \& Snow, A. A. (2001). Seed size variation and predation of seeds produced by wild and crop-wild sunflowers. American Journal of Botany, 88, 623-627. https://doi.org/ $10.2307 / 2657061$

Aref, I. M., El Atta, H. A., Al Shahrani, T., \& Mohamed, A. I. (2011). Effects of seed pre-treatment and seed source on germination of five Acacia spp. African Journal of Biotechnology, 10, 15901-15910. https://doi.org/10.5897/ajb11.1763

Ayari, A., Moya, D., Rejeb, M. N., Ben Mansoura, A., Albouchi, M., De Las Heras, J., ... Henchi, B. (2011). Geographical variation on cone and seed production of natural Pinus halepensis Mill. Forests in Tunisia. Journal of Arid Environments, 75, 403-410. https://doi.org/10.1016/j.jaridenv.2011.01.001

Batabyal, S., Dalal, T., \& Tah, J. (2014). Effects of different seed-sources on germination parameters by means of artificial seed germination of Santalum album L. International Journal of Pure and Applied Bioscience, 2, 149-152.

Bester, C., \& Cronje, C. (2013). Manual for propagation of honeybush seedlings and cuttings. Agricultural Research Council Infruitec-Nietvoorbij, Stellenbosch, South Africa.

Bester, C., Tobutt, K. R., Mansvelt, E. L., Blomerus, L. M., Jolly, N., Pieterse, W.-M., ...Van chalkwyk, D. (2013). The value and impact of the ARC Infruitec-Nietvoorbij genebanks. Proceedings of the $2^{\text {nd }}$ All Africa Horticulture Congress. Acta Horticulture (ISHS), 1007, 975-980. https://doi.org/10.17660/ActaHortic. 2013.1007.117 
Bognounou, F., Thiombiano, A., Oden, P. C., \& Guinko, S. (2010). Seed provenance and latitudinal gradient effects on seed germination capacity and seedling establishment of five indigenous species in Burkina Faso. Tropical Ecology, 51, 207-220.

Braza, R., Arroyo, J., \& García, M. B. (2010). Natural variation of fecundity parameters in a widespread plant with dimorphic seeds. Acta Oecologica, 36, 471-476. https://doi.org/10.1016/j.actao.2010.06.003

Burgos, A., Grez, A. A., \& Bustamante, R. O. (2008). Seed production, pre-dispersal seed predation and germination of Nothofagus glauca (Nothofagaceae) in a temperate fragmented forest in Chile. Forest Ecology and Management, 255, 1226-1233. https://doi.org/10.1016/j.foreco.2007.10.032

Carrió, E., Jiménez, J. F., Sánchez-Gómez, P., \& Güemes, J. (2009). Reproductive biology and conservation implications of three endangered snapdragon species (Antirrhinum, Plantaginaceae). Biological Conservation, 142, 1854-1863. https://doi.org/10.1016/j.biocon.2009.03.025

Dainese, M. (2011). Impact of land use intensity and temperature on the reproductive performance of Dactylics glomerata populations in the Southern Alps. Plant Ecology, 212, 651-661. https://doi.org/10.1007/ s11258-011-9902-6

Dao, M. C. E., Diallo, B. O., \& Kabore-Zoungrana, C. (2012). Fruit and seed production in a natural population of dioecious plant: Piliostigma reticulatum HOSCHT (Capesalpinioïdeae). International Journal of Biological and Chemical Sciences, 6, 11-23. https://doi.org/10.4314/ijbcs.v6i1.2

Das, N. (2014). The effect of seed source variation and presowing treatments on the seed germination of Acacia catechu and Elaeocarpus floribundus species in Bangladesh. International Journal of Forestry Research, 2014, 1-8. https://doi.org/10.1155/2014/984194

Donohue, K., Dorn, L., Griffith, C., Kim, E.-S., Anguilera, A., Polisetty, C. A., \& Schimtt, J. (2005). The evolutionary ecology of seed germination of Arabidopsis thaliana: variable natural selection on germination timing. Evolution, 59, 758-770. https://doi.org/10.1111/j.0014-3820.2005.tb01751.x

Du Preez, J. J., \& Sales, J. (1997). Growth rate of different sexes of the European quail (Coturnix cortunix). British Poultry Science, 38, 314-315. https://doi.org/10.1080/00071669708417994

Ehrlén, J. (1992). Proximate limits to seed production in a herbaceous legume, Lathyrus vernus. Ecology, 73, 1820-1831. https://doi.org/10.2307/1940033

Elliot, C. P., \& Ladd, P. G. (2002). Pollen limitation of fruit set in Western Australian terrestrial orchids. Journal of the Royal Society of Western Australia, 85, 165-168.

García, D., Zamora, R. Gómez, J. M., Jordano, P., \& Hódar, J. A. (2000). Geographical variation in seed production, predation and abortion in Juniperus communis throughout its range in Europe. Journal of Ecology, 88, 436-446. https://doi.org/10.1046/j.1365-2745.2000.00459.x

Griffin, S. R., \& Barret, S. C. (2002). Factors affecting low seed: ovule rations in a spring woodland herb, Trillium grandiflorum (Melanthiaceae). International Journal of Plant Science, 163, 581-590. https://doi.org/10.1086/340814

Hay, F. R., \& Probert, R. J. (2013). Advances in seed conservation of wild plant species: A review of recent research. Conservation Physiology, 1(1), 1-11. https://doi.org/10.1093/conphys/cot030

Herget, M. E., Hufford, K. M., Mummey, D. L., \& Shreading, L. N. (2015). Consequences of seed origin and biological invasion for early establishment in restoration of a North American grass species. Public Library of Science One, 10(3), 1-16. https://doi.org/10.1371/journal.pone.0119889

International Seed Testing Association (ISTA). (2008). Handbook of vigour test methods (3rd ed.). International Seeed Testing Association, Zurich, Switzerland.

Joubert, E., Joubert, M. E., Bester, C., De Beer, D., \& De Lange, J. H. (2011). Honeybush (Cyclopia spp.): From local cottage industry to global markets: The catalytic and supporting role of research. South African Journal of Botany, 4, 887-907. https://doi.org/10.1016/j.sajb.2011.05.014

Joubert, M., \& Joubert, E. (2012). In M. Joubert (Ed.), Farming with honeybush: general guidelines (2nd ed., pp. 1-17). Southern Science.

Kéry, M., Matthies, D., \& Spillmann, H.-H. (2000). Reduced fecundity and offspring performance in small populations of the declining grassland plants Primula veris and Gentiana lutea. Journal of Ecology, 88, 17-30. https://doi.org/10.1046/j.1365-2745.2000.00422.x 
Koen, J., Slabbert, M. M., Bester, C., \& Bierman, F. (2016). Germination characteristics of dimorphic honeybush (Cyclopia spp.) seed. South African Journal of Botany, 110, 68-74. https://doi.org/10.1016/j.sajb.2016. 03.006

Larios, E., Búrquez, A., Becerra, J. X., \& Venable, D. L. (2014). Natural selection on seed size through the life cycle of a desert annual plant. Ecology, 95, 3213-3220. https://doi.org/10.1890/13-1965.1

Lee, T. D., \& Bazzaz, F. A. (1982). Regulation of fruit and seed production in an annual legume, Cassia fasciculata. Ecology, 63, 1363-1373. https://doi.org/10.2307/1938864

Liu, Z., Yan, Q., Li, X., Ma, J., \& Ling, X. (2007). Seed mass and shape, germination and plant abundance in a desertified grassland in northeastern Inner Mongolia, China. Journal of Arid Environments, 69, $198-211$. https://doi.org/10.1016/j.jaridenv.2006.09.012

Löwe, T. R., \& Dillenburg, L. R. (2011). Changes in light and nutrient availabilities do not alter the duration of use of seed reserves in Araucaria angustifolia seedlings. Australian Journal of Botany, 59, 32-37. https://doi.org/10.1071/bt10212

Mabizela, G. S., Slabbert, M. M., \& Bester, C. (2016). The effect of rooting media, plant growth regulators and clone on rooting potential of honeybush (Cyclopia subternata) stem cuttings at different planting date. South African Journal of Botany, 110, 75-79. https://doi.org/10.1016.j.sajb.2016.02.200

Maron, J. L., Vilá, M., Bommarco, R., Elmendorf, S., \& Beardsley, P. (2004). Rapid evolution of an invasive plant. Ecological Monographs, 74, 261-280. https://doi.org/10.1890/03-4027

Mohammadi, G., Khah, E. M., \& Bannayan-Aval, M. (2011). Differential responses for harvesting times and storage on hardness of different varieties of Okra. Notulae Scientia Biologicae, 3, 117-122.

Motsa, M. M., Slabbert, M. M., Bester, C., \& Ngwenya, M. Z. (2016). Phenology of honeybush (Cyclopia genistoides and C. subternata) genotypes. South African Journal of Botany, 110, 57-67. https://doi.org/10.1016/j.sajb.2016.03.005

Motsa, M. M., Slabbert, M. M., Bester, C., Mokwena, L., \& Taylor, M. (2017). Volatile organic compounds from germinating seeds of cyclopia species as affected by temperature. Seed Science and Technology, 45(1), 1-13. https://doi.org/10.15258/sst.2017.45.1.22

Motsa, M. M., Slabbert, M. M., Van Averbeke, W., \& Morey, L. (2015). Effect of light and temperature on seed germination of selected African leafy vegetables. South African Journal of Botany, 99, 29-35. https://doi.org/10.1016/j.sajb.2015.03.185

Muller-Landau, H. C. (2010). The tolerance-fecundity trade off and the maintenance of diversity in seed size. In S. A. Levin (Ed.), Proceedings of the National Academy of Sciences of the United States of America, 107, 4242-4247. https://doi.org/10.1073/pnas.0911637107

Parra-Tabla, V., Vargas, C. F., \& Egiarte, L. E. (1998). Is Echeveria gibbiflora (Crassulaceae) fecundity limited by pollen availability? An experimental study. Functional Ecology, 12, 591-595. https://oi.org/10.1046/ j.1365-2435.1998.00229.x

Paz, L., \& Vázquez-Yanes, C. (1998). Comparative seed ecophysiology of wild and cultivated Carica papaya trees from a tropical rain forest region in Mexico. Tree Physiology, 18, 277-280. https://doi.org/10.1093/ treephys/18.4.277

Podleśny, J., \& Podleśna, A. (2012). The effect of high temperature during flowering on growth, development and yielding of blue lupine - barley mixture. Journal of Food, Agriculture and Environment, 10, 500-504.

Price, M. V., Campell. D. R., Waser, N. M., \& Brody, A. K. (2008). Bridging the generation gap in plants: Pollination, parental fecundity, and offspring demography. Ecology, 89, 1596-1604. https://doi.org/10.1890/ 07-0614.1

Pringle, A., Chen, D., \& Taylor, J. W. (2003). Sexual fecundity is correlated to size in the linchinized fungus Xanthoparmelia cumberlandia. The Bryologist, 106, 221-225. https://doi.org/10.1639/0007-2745(2003)106 [0221:SFICTS]2.0.CO;2

Qiu, J., Bai, Y., Fu, Y.-B., \& Wilmshurst, J. T. (2010). Spatial variation in temperature thresholds during seed germination of remnant Festuca hallii populations across the Canadian prairie. Environmental and Experimental Botany, 67, 479-486. https://doi.org/10.1016/j.envexpbot.2009.09.002 
Rojas-Aréchiga, M., Casas, A., \& Vázquez-Yanes, C. (2001). Seed germination of wild and cultivated Stenocereus stellas (Cataceae) from the Tehuacán-Cuicatlán valley, Central Mexico. Journal of Arid Environments, 49, 279-287. https://doi.org/10.1006/jare.2001.0789

Sardans, J., \& Peñuelas, J. (2013). Plant-soil interactions in Mediterranean forest and shrublands: impacts of climatic change. Plant and Soil, 365, 1-33. https://doi.org/10.1007/s11104-013-1591-6

Schurr, F. M., Steinitz, O., \& Nathan, R. (2008). Plant fecundity and seed dispersal in spatially heterogeneous environments: Models, mechanisms and estimation. Journal of Ecology, 96, 628-641. https://doi.org/ 10.1111/j.1365-2745.2008.01371.x

Schutte, A. L. (1997). Systematics of the genus Cyclopia Vent. (Fabaceae, Podalyrieae). Edinburgh Journal of Botany, 54, 125-170. https://doi.org/10.1017/S0960428600004005

Shapiro, S. S., \& Wilk, M. B. (1965). An analysis of variance test for normality (complete samples). Biometrika, 52, 591-611. https://doi.org/10.1093/biomet/52.3-4.591

Sharma, A., \& Bakshi, M. (2014). Variability in growth, physiological and biochemical characteristics among various clones of Dalbergia sissoo in a clonal seed orchard. International Journal of Forestry Research, 2014, 1-9. https://doi.org/10.1155/2014/829368

Silvertown, J. W. (1984). Phenotypic variety in seed germination behaviour: The ontogeny and evolution of the somatic polymorphism in seeds. The American Naturalist, 124(1), 1-16. https://doi.org/10.1086/284249

Slabbert, E. L. (2016). Potential ecosystem services and disservices of arthropods associated with Cyclopia (honeybush) species (Unpublished M.Sc. thesis). Stellenbosch University, South Africa.

Snow, A. A., Pilson, D., Rieseberg, L. H., Paulsen, M. J., Pleskac, N., Reagon, M. R., ... Selbo, S. M. (2003). A $\mathrm{Bt}$ transgene reduces herbivory and enhances fecundity in wild sunflowers. Ecological Applications, 13, 279-286. https://doi.org/10.1890/1051-0761(2003)013[0279:ABTRHA]2.0.CO;2

Susko, D. J., \& Lovett-Doust, L. (2000). Patterns of seed mass variation and their effects on seedling traits in Alliaria petiolta. American Journal of Botany, 87, 56-66. https://doi.org/10.2307/2656685

Teixeira, S. D.-P., Pareira, R. A. S., \& Ranga, N. T. (2006). Components of fecundity and abortion in a tropical tree, Dahlstedtia pentaphylla (Leguminosae). Brazilian Archives of Biology and Technology, 49, 905-913. https://doi.org/10.1590/S1516-89132006000700007

Thuzar, M., Puteh, A.B., Abdullah, N.A.P., Lassim, M.B.M. \& Jusoff, K. (2010). The effects of temperature stress on the quality and yield of soya bean [(Glycine max L.) Merrill.]. Journal of Agricultural Sciences, 2, 172-179. https://doi.org/10.5539/jas.v2n1p172

Toth, I., Dragomir, N., \& Neagu, A. (2013). Long-run study of the share of hard seeds in Lotus corniculatus L. Animal Science and Biotechnologies, 46, 153-157.

Valtueña, F. J., Ortega-Olivencia, A., Rodríguez-Riaño, T., \& López, J. (2010). Causes of low fruit and seed set in bird-pollinated Anagris foetida (Leguminosae): Pollen limitation and extrinsic factors. Folia Geobotanica, 45, 77-94. https://doi.org/10.1007/s12224-009-9054-9

Vitasse, Y., Delzon, S., Bresson, C. C., Michalet, R., \& Kremer, A. (2009). Altitudinal differentiation in growth and phenology among populations of temperate-zone tree species growing in a common garden. Canadian Journal of Forest Research, 39, 1259-1269. https://doi.org/10.1139/x09-054

\section{Copyrights}

Copyright for this article is retained by the author(s), with first publication rights granted to the journal.

This is an open-access article distributed under the terms and conditions of the Creative Commons Attribution license (http://creativecommons.org/licenses/by/4.0/). 